\title{
From the Editor in Chief
}

Dear producers and consumers of knowledge,

I would like to share the happiness of being with you again with forth issue of Pegem Journal of Education and Instruction (PEGEGOG) in 2019. Initially, I want to thank you for the increasing interest for our journal.

In this issue, I am pleased to inform you that our journal has started to be indexed in ERIC database as well. With this good news, there has been a significant increase in the number of submissions to our journal. Although this interest in our journal has pleased us, I would like to inform that we will be more selective in order to improve our publication quality. Therefore, I recommend you, dear science producers, to carefully examine the author's guide before submitting your article.

One hundred and eighty-three manuscripts were submitted to PEGEGOG in last one year. Of these, about $25.00 \%$ were accepted for publication. This is good news for our journal. On the other hand, I have to indicate that there were critical problems in terms of format within these articles as stated in the previous issue. First of all, unfortunately we had to reject some articles as in many of them there were texts very similar to ones in different articles. At first step, we scan all articles in i-Thenticate program to determine the exact quotations from other resources. After this scan, we reject the articles detected to have exact quotations at a high rate without initiating peer-review process. Apart from that, we also send back the articles not written in an academic format not to disturb our reviewers unnecessarily.

One of the problems with the articles submitted to our journal and we had to reject was about data analysis. The data is the raw information collected from related resources through research aims. These should be analyzed in parallel with these aims. It is necessary to analyze them using statistics for quantitative data and methods such as content analysis or descriptive analysis for qualitative data. Analysis provides the data being transformed into findings and make sense. Especially, in some of document analysis and some qualitative studies, it is seen that data are presented as findings. In some others, data are presented being only described. It is essential that the studies are formed in an article format obeying the rules by the journal and presented for publication afterwards.

As always, we present the ten articles got through peer-review process and given DOI number to you dear producers and consumers of knowledge. I wish these studies conducted in various fields of educational sciences will be useful and contribute to theoretical knowledge within the field. Hope to meet within the next issue.

Sincerely yours,

Prof. Dr. Ahmet DOĞANAY

Editor in Chief 


\section{Editörden}

Değerli bilgi üretici ve tüketicileri,

Pegem Eğitim ve Öğretim Dergisi'nin (PEGEGOG) 2019 yılı dördüncü sayısı ile sizlerle bir kez daha beraber olmaktan duyduğum mutluluğu paylaşmak istiyorum. Öncelikli olarak dergimize olan ilginin sürekli artması nedeniyle sizlere teşekkür etmek isterim.

$\mathrm{Bu}$ sayıda sizlere dergimizin ERIC veri tabanında da taranmaya başladığını bildirmekten ayrı bir mutluluk duyuyorum. Bu güzel haberle birlikte dergimize başvuru sayısında ciddi bir artış oldu. Dergimize gösterilen bu ilgi bizi sevindirmiş olsa da yayın kalitemizi daha üst seviyelere taşımak amacıyla daha seçici davranacağımızı bildirmek isterim. Bu nedenle siz değerli bilim üreticilerinin makale başvurularını yapmadan önce yazar rehberini dikkatli incelemesini önermekteyim.

PEGEGOG dergisine, son bir yıl içinde 183 makale başvurusu yapılmıştır. Bunların yaklaşık\% 25.00’i yayına kabul edilmiştir. Bu, dergimiz için sevindirici bir haberdir. Ancak üzülerek belirtmem gerekiyor ki, önceki sayıda belirttiğimiz gibi bu makalelerin bazılarında format açısından önemli sorunlar vardı. Öncelikle birçok yazarımızın makalesindeki metinlerin başka makale ya da metinlerle birebir benzerliği nedeniyle üzülerek ret etmek zorunda kaldık. Bize gelen tüm makaleleri ilk önce I-thenticate programıyla diğer kaynaklardan birebir alıntıları belirlemek için tarıyoruz. Bu tarama sonucunda yüksek oranda birebir alıntı olduğu belirlenen makaleleri hakem sürecine göndermeden ret ediyoruz. Bunun dışında, bir akademik makale formatına uymayan çalışmaları da hakemlerimizi boş yere yormamak adına geri çeviriyoruz.

Dergimize yapılan başvurularda ret etmek zorunda kaldığımız çalışmaların bir kısmında görülen sorunlardan birisi de veri analiziyle ilgiliydi. Veri, araştırma amaçları doğrultusunda ilgili kaynaklardan toplanan ham bilgilerdir. Bunların amaçlar doğrultusunda analiz edilmesi gerekir. Veriler sayısal ise istatistik teknikleri kullanarak nitel ise içerik analiz ya da betimsel analiz yöntemleri gibi yöntemlerle analiz etmek gerekir. Analiz verilerin bulguya dönüşmesini ve onlardan anlam çıkarılmasını sağlar. Özellikle belge analizi ve diğer nitel çalışmaların bazılarında verilerin bulgu olarak sunulduğu görülmektedir. Bazılarında ise veriler sadece betimlenerek sunulmaktadır. Başvuru yapılmadan önce çalışmaların derginin benimsediği kurallara uyarak makale formatına getirilmesi ve ondan sonra yayım için sunulması gerekmektedir.

Bu sayımızda da her zaman olduğu gibi hakem değerlendirme süreci tamamlanan ve daha önce DOI numarası verdiğimiz on makaleyi siz değerli bilgi üreticisi ve tüketicilerinin hizmetine sunuyoruz. Eğitim bilimlerinin çeşitli alanlarında yapılan bu çalışmaların yararlı olmasını ve eğitim uygulamalarına ve eğitim bilimleri alanındaki kuramsal bilgi birikimine katkı yapmasını diliyor, gelecek sayıda buluşmak dileğiyle en içten saygılarımı sunuyorum.

Prof. Dr. Ahmet DOĞANAY

Baş Editör 